\title{
Testing and Evaluation of a Carrying Capacity of Existing Bridges
}

\author{
Ren Ping \\ School of Civil Engineering \\ Henan University of Urban Construction \\ Pingdingshan, China \\ 14851338@qq.com
}

\author{
Han Jian \\ School of Civil Engineering \\ Henan University of Urban Construction \\ Pingdingshan, China \\ 10934616@qq.com
}

\begin{abstract}
In the paper, we combined with an actual engineering about an old bridge which filling pile. Through conducting the structure performance testing and cap beam Carrying Capacity of the old bridge, and using the comprehensive assessment method grading the old bridge, these provide a scientific basis for the old bridge reinforcement in the future. The analysis results showed that, the bridge site conditions in which poor, severely damaged steel and concrete structures, poor structural performance, Carrying Capacity of the main members does not meet the requirements of the highway bridge load rating at the present stage, the rating is four. When the live load is arranged along the bridge, take the continuous two-span along the bridge, the live load bearing reaction force of the maximum separately were calculated, which under the action of car -20 , trailer-100 and the crowd load and with single span and double span arrangement.This bridge belongs to comprehensive assessment method in the fourth type bridge, there is a big security risk, must reinforced timely.
\end{abstract}

KeyWords-Structural properties; Comprehensive Assessment; Carrying Capacity;testing ;evaluation

\section{【CLC】 : TU 528.572 【Document code】 : A}

\section{FOREWORD}

The original technical standards of highway bridges in china is low, the capacity is poor, with the increasing road traffic, roads and bridges carrying capacity is obviously insufficient, directly affect the safety of bridges and damage, practicality and durability. A filling pile of old bridge structure type was fabricated concrete
I- beam bridge deck Simply Supported Bridge, built 60s. Deck Width: Net $8+2 \times 1.0 \mathrm{~m}$, standard span: LB = $18.80 \mathrm{~m}$ (pier center distance), calculation of span: $\mathrm{L}=$ $18.00 \mathrm{~m}$ (bearing center distance). Currently the bridge with varying diseases, therefore, the bridge structure detection and Bearing Capacity study and use of integrated assessment methods were grading the old bridge to provide a scientific basis for the safe use of the old bridge.

\section{STRUCTURE PERFORMANCE TESTING}

\section{A Structure Current Situation Survey}

From the deck to the riverbed above the visible part, a detailed investigation records deck situation (pavement, marks limited line, drainage, expansion joints, railings, rail line board, etc.), bridge abutments' concrete cracks, weathering, flaking, exposed reinforcement, corrosion, appearance of construction quality, etc.

\section{$B \quad$ The strength of concrete}

Using the rebound method combined with the coring correction to test the strength of concrete, the strength of various types of concrete members inferred statistical results shown in Table 1. [1] The measured basically meets the design requirements of the strength of concrete, indicating that the use of nearly five decades later, the bridge was not damaged parts of the main structure of the strength of concrete to meet the design requirements.

TABLE I. MEMBER CONCRETE STRENGTH TESTING (UNIT: MPA)

\begin{tabular}{cccc}
\hline Member name & Max (MPa) & Min (MPa) & $\begin{array}{c}\text { Estimated value } \\
(\mathrm{MPa})\end{array}$ \\
\hline Bridge column I & 39.1 & 31.2 & 34.2 \\
Bridge column II & 38.3 & 32.9 & 33.8 \\
Bridge columnIII & 36.9 & 31.8 & 32.9 \\
Cap beam I & 38.4 & 31.6 & 33.8 \\
Cap beam II & 35.7 & 28.0 & 31.3 \\
\hline
\end{tabular}




\section{III. . CALCULATING THE BEARING CAPACITY OF CAP BEAM}

\section{A The load Calculation}

The bridge calculation load was divided into two parts, dead load and live load, the load by 5 cover plates directly acted on cap beam, shown in Fig .1. Dead load [2] is composed of the weight of the upper structure of the bridge, take representative a span bridge dead load to calculate.

There are two load live load calculation methods are arranged, along the bridge to the live load and live load arranged horizontal layout [3], according to the movement of live load, the maximum live load bearing reaction force are obtained. When the live load lateral distribution, the symmetrical arrangement using leveraged method, asymmetrical arrangement using eccentric compression method, are calculated 5 piece of cover plates of bridge panel, and transverse distribution coefficient kn obtained separately. Thus we can calculated separately the live load bearing reaction force of the maximum [4], which under the action of single column car -20 , double columns car -20 , trailer-100 and the crowd load. [5] When the live loadis arranged along the bridge, take the continuous two-span along the bridge, the live load bearing reaction force of the maximum separately were calculated, which under the action of car -20, trailer-100 and the crowd load and with single span and double span arrangement [6].

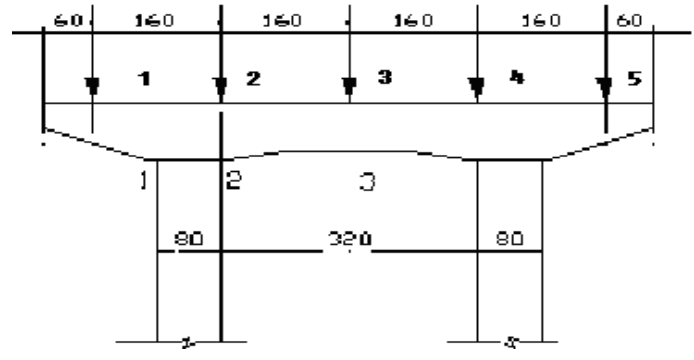

Figure 1. Load distribution

\section{B Reaction forces of dead load, live load combination}

Calculation are shown in Table 2 and table are drawn the maximum value of each plate, its impact coefficient is: $1+\mu=1.085$, influence line length according to the double holes count, $2 \times 16.15=32.3 \mathrm{~m}$, the impact coefficient caused by vehicle load in the table has been included.

Live load combined load by 5 cover plates effect on the beam directly, function diagram as shown in Fig .1. 13 set of each section of the internal force Ri under dead load and the cooperation load as shown in the table 3 .

According to the original design data of the bridge and field structure surveys to obtain reinforcement of each section are shown in Table 4.

TABLE II. PLATE DEAD LOAD, LIVE LOAD COMBINATION REACTION FORCE (UNIT: KN)

\begin{tabular}{ccccccc}
\hline Number & Load condition & $1^{\text {st }}$ beam & $2^{\text {nd }}$ beam & $3^{\text {rd }}$ beam & $4^{\text {th }}$ beam & $5^{\text {th }}$ beam \\
\hline 1 & Dead load & 489.22 & 270.82 & 270.82 & 270.82 & 489.22 \\
2 & $\begin{array}{c}\text { car -20, double row } \\
\text { symmetrical }\end{array}$ & 84.15 & 138.56 & 187.91 & 138.56 & 84.15 \\
3 & $\begin{array}{c}\text { Car -20, double row } \\
\text { asymmetric }\end{array}$ & $170.19-$ & 148.05 & 126.54 & 105.02 & 82.88 \\
4 & Trailer -100 symmetry & 0 & 237.87 & 370.77 & 237.87 & 0 \\
5 & Trailer -100 asymmetric & 291.21 & 230.25 & 169.30 & 108.35 & 47.40 \\
6 & Crowd symmetry & 52.14 & 15.46 & 0 & -15.46 & -52.14 \\
7 & Crowd asymmetric & 25.08 & 16.20 & 7.34 & -1.54 & -10.42 \\
8 & (1)+(2)+(6) & 625.51 & 424.84 & 458.73 & 393.92 & 521.23 \\
9 & (1)+(2)+(7) & 598.45 & 425.58 & 466.07 & 407.84 & 562.95 \\
10 & (1)+(3)+(6) & 541.36 & 434.33 & 397.36 & 360.38 & 519.96 \\
11 & (1)+(3)+(7) & 514.3 & 435.07 & 404.7 & 374.3 & 561.68 \\
12 & (1)+(4)/1.25 & 489.22 & 461.12 & 567.44 & 461.12 & 489.22 \\
13 & (1)+(5)/1.25 & 722.19 & 455.02 & 406.26 & 357.5 & 527.14 \\
\hline
\end{tabular}


TABLE III. SUMMARY OF CAP BEAM INTERNAL FORCE

\begin{tabular}{|c|c|c|c|c|c|}
\hline & \multicolumn{2}{|c|}{ Internal force } & $1-1$ & $2-2$ & $3-3$ \\
\hline \multirow{3}{*}{$\begin{array}{l}\text { Moment } \\
(\mathrm{kN} \cdot \mathrm{m})\end{array}$} & \multicolumn{2}{|c|}{$M_{\text {deadweight }}$} & 7.4 & -27.80 & -25.35 \\
\hline & \multicolumn{2}{|c|}{$M_{\text {load }}$} & -113.57 & -477.65 & -437.86 \\
\hline & \multicolumn{2}{|c|}{$M_{\text {calculation }}$} & -106.17 & -583.89 & -463.21 \\
\hline & $Q$ deadweight & L & 0 & 46.00 & -39.00 \\
\hline & $Q$ deadweight & $\mathrm{R}$ & 0 & 46.00 & -39.00 \\
\hline Shear & $Q_{\text {load }}$ & $\mathrm{L}$ & 257.56 & 682.40 & 0 \\
\hline \multirow[t]{3}{*}{$(\mathrm{kN})$} & $Q_{\text {load }}$ & $\mathrm{R}$ & -201.17 & 257.56 & -625.51 \\
\hline & $Q_{\text {calculation }}$ & $\mathrm{L}$ & 257.56 & 728.40 & -39.00 \\
\hline & $Q_{\text {calculation }}$ & $\mathrm{R}$ & -201.17 & 303.56 & -664.51 \\
\hline
\end{tabular}

\section{Cap Beam Bearing Capacity Calculation}

TABLE IV. CAP BEAM REINFORCEMENT OF EACH SECTION

\begin{tabular}{ccccc}
\hline $\begin{array}{c}\text { Section } \\
\text { number }\end{array}$ & $\begin{array}{c}\text { The number } \\
\text { of } \\
\text { longitudinal } \\
\text { reinforcement }\end{array}$ & $\begin{array}{c}\text { Reinforced area } \\
\left(\mathrm{mm}^{2}\right)\end{array}$ & $\begin{array}{c}\text { Reinforcement } \\
\text { ratio }\end{array}$ & $\begin{array}{c}\text { Stirrups diameter and } \\
\text { spacing }\end{array}$ \\
\hline $1-1$ & $6 \Phi 20$ & 1884 & $0.3 \%$ & $4 \varnothing 8 @ 190$ \\
$2-2$ & $6 \Phi 20$ & 1884 & $0.3 \%$ & $4 \varnothing 8 @ 190$ \\
$3-3$ & $4 \Phi 20$ & 1256 & $0.2 \%$ & $4 \varnothing 8 @ 190$ \\
\hline
\end{tabular}

After checking, the cap beam flexural and shear accepted standards under the trailer-100 load, the need capacity don't meet the requirements of presently for structural reinforcement.

TABLE V. WEIGHTS OF THE COMPONENTS OF BRIDGES AND A COMPREHENSIVE ASSESSMENT

\begin{tabular}{|c|c|c|c|c|c|c|c|c|}
\hline $\begin{array}{c}\mathrm{Nu} \\
\mathrm{mb} \\
\mathrm{er}\end{array}$ & member & $\begin{array}{c}\text { Weights } \\
W_{i}\end{array}$ & $\begin{array}{l}\text { Parts } \\
\text { defect } \\
\text { degree } \\
\text { scale }\end{array}$ & $\begin{array}{l}\text { Defects } \\
\text { affect use } \\
\text { function }\end{array}$ & $\begin{array}{l}\text { Defect } \\
\text { developme } \\
\text { nt situation } \\
\text { correction }\end{array}$ & $\begin{array}{l}\text { Evaluati } \\
\quad \text { on } \\
\text { results } R_{i}\end{array}$ & $W_{i} R_{i .}$ & note \\
\hline 1 & $\begin{array}{l}\text { Wing wall, ear } \\
\text { Wall }\end{array}$ & 1 & 0 & 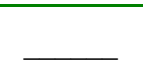 & 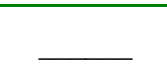 & 0 & 0 & no \\
\hline 2 & $\begin{array}{l}\text { Cone slope, slope } \\
\text { protection }\end{array}$ & 1 & 1 & 2 & 2 & 5 & 5 & \\
\hline 3 & $\begin{array}{l}\text { Bridge Abutment } \\
\text { and foundation }\end{array}$ & 23 & 1 & 2 & 3 & 6 & 138 & \\
\hline 4 & $\begin{array}{l}\text { Bridge pier and } \\
\text { foundation }\end{array}$ & 24 & 1 & 2 & 2 & 5 & 120 & \\
\hline 5 & Foundation scour & 8 & 1 & 1 & 1 & 3 & 24 & \\
\hline 6 & Bearing & 3 & 2 & 2 & 1 & 5 & 15 & \\
\hline 7 & $\begin{array}{l}\text { Upper main bearing } \\
\text { component }\end{array}$ & 20 & 2 & 2 & 1 & 5 & 100 & \\
\hline 8 & $\begin{array}{c}\text { Upper general } \\
\text { bearing component }\end{array}$ & 5 & 2 & 3 & 1 & 6 & 30 & \\
\hline 9 & $\begin{array}{l}\text { Bridge deck } \\
\text { pavement }\end{array}$ & 1 & 2 & 1 & 1 & 4 & 4 & \\
\hline 10 & $\begin{array}{l}\text { Bridge and } \\
\text { embankment } \\
\text { connecting portion }\end{array}$ & 3 & 2 & 2 & 1 & 5 & 15 & \\
\hline 11 & Expansion Joints & 3 & 2 & 1 & 0 & 3 & 9 & \\
\hline 12 & Sidewalk & 1 & 2 & 2 & 1 & 5 & 5 & \\
\hline 13 & Railing, fence & 1 & 2 & 1 & 1 & 4 & 4 & \\
\hline 14 & Lamps, sign & 1 & 2 & 3 & 0 & 5 & 5 & \\
\hline 15 & Drainage facilities & 1 & 2 & 1 & 1 & 4 & 4 & \\
\hline 16 & $\begin{array}{c}\text { Modulation } \\
\text { structure }\end{array}$ & 3 & 0 & & 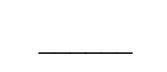 & 0 & 0 & no \\
\hline 17 & Other & 1 & 0 & 0 & 0 & 0 & 0 & $\begin{array}{l}\text { No } \\
\text { lightnin } \\
\text { g rod } \\
\text { etc. }\end{array}$ \\
\hline
\end{tabular}

NOTE: $D_{\mathrm{r}}$ - whole bridge technical condition score (0-100), high score represents the bridge having good technical condition; $R_{\mathrm{i}}-$ according to the following table method for each component evaluation scale (0-5); $W_{i}$ - bridge weight of the components. 


\section{COMPREHENSIVE ASSESSMENT OF THE BRIDGE}

According to the bridge filed investigation [7], the bearing capacity of structure detection and calculation results, combined with specification conducted a comprehensive assessment of this bridge, the results shown in Table 5.

Comprehensive evaluation standard reference specification: the fourth type bridge's overall assessment standards, important components have serious functional diseases, and there is the continued expansion of the phenomenon, part of the material strength of the key parts to the limit, fracture appeared partially reinforced, concrete crushed or Rod member instability deformation failure phenomena, deformation is greater than the specified value [8], Structural strength, stiffness, stability and dynamic response can't reach the usual requirements for the safe passage of traffic. According to the results of testing and checking calculation, the bridge $30 \%$ to $40 \%$ of the important component materials has serious defect [9], crack width gauge, weathered, peeling, exposed tendons, corroded severely and developed rapidly, function was significantly reduced. [10] More than $40 \%$ of secondary members has serious defect, serious impact on traffic safety. After investigation and assessment, this bridge belongs to the fourth bridge, there is a big security risk, must be treated promptly.

\section{$\mathrm{V}$. CONCLUSIONS}

(1) Special test results showed that the old bridge: the structural condition of the bridge which the poor, the function was significantly reduced.

(2) Cap beam structure of the bridge checking calculation results show: the bridge bearing capacity of existing capping beam can't meet the requirements of the current highway bridge load level. This bridge belongs to comprehensive assessment method in the fourth type bridge, there is a big security risk, must reinforced timely.

\section{REFERENCES}

[1] People's Republic of China Industry Standard Specification for Highway Bridges and Culverts Conservation (JTG H11-2004) Beijing: china communications press, 2004

[2] Hendriks C F,Pieterson H S.Sustainable raw materials construction and demolition waste[M]. RILEM Report 22, RILEM Publication Serie, F-94235 Cachan Cedex, France. 1998.

[3] SHI Yun. study on practical grading standard of security of bearing capacily of existing bridge members[J].Journal of highway and Transportation Researchi and Development,2010(12)

[4] LI Quan-wang. Relianility-based capacity assessment of exisiting bridges[J].ENGINEERING MECHANICS,2010(12)

[5] LI Wen-tao.The Dynamic Method for Evaluating the Bearing Force of Exist Bridge[J].Communications Standardization,2007

[6] HOU Fa liang .The Application of Steel-bonded Strengthening Technology in Enhancing the Carrying Capacity of Existing Bridges. Bridge Construction, 2000

[7] DENG Gui-ping .Comparison on evaluation methods of bridge loading capacity,Shanxi Architecture,2009

[8] YAN Lei .Assessment on the bearing capacity of an existing bridge based on reliability.Journal of Xi'an University of Architecture \& Technology,2010

[9] Zhang Yanling .Research into the Evaluation Approaches to the Bearing Capacity of Existing Bridges.Traffic Engineering and Technology for National Defence ,2003

[10] Zhang Yufeng .Contrast and Research on Carrying Capacity Evaluation Measure of Highway Bridges in the United States and China.Modern Transportation Technology,2009 